\section{SOI: $1.1 /$ TAS $\quad$ DOI: $10.15863 /$ TAS}

\section{International Scientific Journal}

\section{Theoretical \& Applied Science}

p-ISSN: 2308-4944 (print) $\quad$ e-ISSN: 2409-0085 (online)

Year: $2015 \quad$ Issue: $07 \quad$ Volume: 27

Published: $30.07 .2015 \quad \underline{\text { http://T-Science.org }}$

SECTION 31. Economic research, finance, innovation, risk management.
Lyazzat Kairatovna Mukhambetova

Candidate of economic siences, docent, Kazakh University of Economics, Finance and International trade

Astana, Kazakhstan $\underline{\text { lmuhambetova@mail.ru }}$

Karlygash Tanatarovna Auyezova Candidate of technical siences, docent, L.N.Gumilyov Eurasian National University Astana, Kazakhstan

Aliya Zhussanbayeva Master of management, senior lecturer, Taraz State University Taraz, Kazakhstan

\title{
JSC «KAZPOST» NATIONAL POSTAL OPERATORS: OF REFORMS TO STRATEGIC DEVELOPMENT
}

Abstract: The article presents the results of a study of reform in the postal industry and the current state of the Republic of Kazakhstan. Also results of activity "Kazpost» as the national postal operator. The authors' conclusions are based on an analysis of official statistical numbers and results of policies of the company. The results SWOT-analysis allowed to develop a set of measures to improve the company's strategy for the short and medium term.

Key words: postal service, postal services, postal savings system, postal administration, development strategy.

Language: Russian

Citation: Mukhambetova LK, Auyezova KT, Zhussanbayeva A (2015) JSC «KAZPOST» NATIONAL POSTAL OPERATORS: OF REFORMS TO STRATEGIC DEVELOPMENT. ISJ Theoretical \& Applied Science 07 (27): 20-29.

Soi: http://s-o-i.org/1.1/TAS-07-27-4 Doi: crossef http://dx.doi.org/10.15863/TAS.2015.07.27.4

\section{АО "КАЗПОЧТА" КАК НАЦИОНАЛЬНЫЙ ОПЕРАТОР ПОЧТОВОЙ СВЯЗИ: ОТ РЕФОРМ К СТРАТЕГИЧЕСКОМУ РАЗВИТИЮ}

Аннотация: В статье представлены результаты исследования реформирования почтовой отрасли РК и современного состояния АО "Казпочта" как национального оператора почтовой связи. Выводы авторов основаны на анализе официальной отчетности и стратегий развития компании. Проведенньй SWOT-анализ позволил разработать комплекс мер по совершенствованию стратегий развития компании на краткосрочный и среднесрочный периоды.

Ключевые слова: почтовая связь, почтовые услуги, почтово-сберегательная система, почтовая администрация, стратегия развития

В Казахстане, взявшем курс на индустриально-инновационное развитие экономики, развитие инфокоммуникационных технологий и почтовой связи является одним из важных приоритетов. И для этого есть все предпосылки. Так, в стране наблюдается значительный рост количества Интернетпользователей, интенсивно развивается электронная коммерция, растет количество услуг и потребителей услуг "е-правительства". Вместе с тем, в республике ощущается потребность в предоставлении качественных финансовых услуг населению и бизнесу, особенно в сельской местности, где кроме почты не представлены никакие другие структуры. Учитывая уникальное географическое положение Казахстана между Китаем, Юго-Восточной Азией и Европой, растет потребность в транспортно-логистических услугах как внутри страны, так и со стороны международного бизнеса. Постоянно растут объемы пересылаемых посылок, что связано с бурным развитием торговли через Интернет и по каталогам. Именно поэтому дистанционная торговля становится одним из перспективных направлений развития почтового бизнеса. Увеличение объемов корпоративной корреспонденции и рекламных рассылок еще раз демонстрирует потенциальные возможности традиционной почты. 
Казахстан стал первой страной на постсоветском пространстве, принявшей за основу почтово-сберегательную модель ведущих стран мира, эффективность которой подтверждается зарубежным опытом и достигнутыми положительными результатами отечественного оператора почты за последние годы развития. По такому же пути развивают почтовую отрасль страны СНГ и Балтии. В соответствии с Законом РК "О почте" АО "Казпочта" как Национальный оператор почты является проводником государственной политики по развитию в стране почтово-сберегательной системы. Тем не менее, несмотря на то, что Компания предоставляет все банковские услуги, за исключением кредитования, главной ее миссией остается предоставление качественных услуг почтовой связи. Однако географические и экономико-демографические особенности Казахстана, включая большую протяженность территории, низкую и неравномерную плотность населения, отдаленность населенных пунктов друг от друга, а также невысокая платежеспособность сельского населения, негативно влияют на перспективы развития почтовых услуг в Казахстане.

В рейтинге качества работы национальных компаний РК за 2013 год АО "Казпочта" входит в последнюю пятерку компаний. Компания проигрывает конкуренцию на внутреннем рынке ведущим мировым почтовым агентам, не обеспечивает оперативности обработки корреспонденции и посылок, имеет тарифы, превышающие тарифы частных курьерских организаций. Согласно оценке исследовательного агентства "Рейтинг.kz", несмотря на достаточно высокие финансовые вложения со стороны государства, на сегодняшний день деятельность национальных компаний не является эффективной. В этом смысле АО "Казпочта" не является исключением. Практически все национальные компании стремятся в первую очередь к увеличению прибыли через удорожание тарифов. В то время как необходима смена парадигмы их развития, когда во главу угла должны быть поставлены интересы поддержания социальной стабильности и повышения социальной ответственности.

АО "Казпочта" является почтовосберегательной системой с разветвленной сервисной сетью отделений связи по всей территории Республики Казахстан. Следует отметить, что казахстанская почта имеет давние исторические традиции. Так, согласно архивным данным, в 1860 году открылось первое почтовое отделение связи в г. Верный (г. Алматы), вскоре преобразованное в почтово-телеграфную контору. К 1883 году конторе подчинялось 14 почтовых отделений связи. На обширной территории дореволюционного Казахстана насчитывалось примерно 250 почтовотелеграфных предприятий. Общая протяженность конно-почтовых трактов составляла около 20 тыс. км. Первая мировая война подорвала почтовое хозяйство Российской империи, а за годы гражданской войны и интервенции хозяйство пришло в полный упадок.

Советское правительство предприняло ряд мер, направленных на восстановление почтовой связи. В начале 20-х годов XX века почтовотелеграфное управление (г. Оренбург) было преобразовано в Киргизский почтовотелеграфный округ, который в 1925 году переименовали в Казахское областное управление связи Наркомата почт и телеграфов СССР. Была учреждена должность сельского письмоносца, организована кольцевая конная почта, в городах конная перевозка почты заменялась автомобильной, стали использоваться ведомственные катера и железнодорожный транспорт. В 1929 году первая почтовая авиалиния связала города Алма-Ату и Ташкент. В 1930 году в Казахстане насчитывалось 1250 почтово-телеграфных предприятий, а протяженность почтовых трактов достигла 42 тыс. км. К 1940 году количество предприятий связи в республике возросло до 1987, было механизировано более 20 тыс. км почтовых трактов. В годы Великой Отечественной войны почтовая служба обеспечивала связь в армии и тылу, а также между фронтом и тылом. Особые трудности были связаны с тем, что большое количество квалифицированных связистов было призвано в армию.

В 1946 году Уполномоченный Народного Комиссариата связи СССР был переименован в Уполномоченного Министерства связи СССР при Совете Министров Казахской ССР. В 1954 году на его основе было организовано Министерство связи Казахской ССР. С середины 60-х годов в Казахстане функционировало более 4000 отделений связи с полным спектром почтовых услуг. Основная часть доходов почтовой связи обеспечивалась за счет доставки пенсий и предоставления телеграфно-телефонных услуг [1].

Резкое изменение ситуации в отрасли произошло после приобретения Казахстаном независимости и суверенитета. Либерализация цен и нарушение стройной системы почтовой связи бывшего Советского Союза повлекло за собой уменьшение количества почтовых отправлений и сокращение отделений связи по всей республике. В 1993 году произошло разделение почтовой и электрической связи. Услуги телекоммуникаций были переданы вновь созданному республиканскому государственному предприятию коммуникаций (впоследствии - 
ОАО "Казахтелеком"), а почтовые услуги оставлены за Службой почтовой связи. Позднее республиканское государственное предприятие почтовой связи было преобразовано в ОАО "Казпочта" при Министерстве транспорта и коммуникаций со $100 \%$ участием государства [2]. В 2000 году Компания зарегистрировала новый Устав в форме открытого акционерного общества, а в 2004 году ОАО "Казпочта" было перерегистрировано в АО "Казпочта" [3].

Программа развития почтовой отрасли и формирования почтово-сберегательной системы на 2000-2003 годы положила начало созданию в Казахстане почтово-сберегательной системы на базе розничной сети отделений почтовой связи. Реформирование казахстанской почтовой отрасли осуществлялось в 2 этапа. На первом этапе планировались становление почтовосберегательной системы, модернизация почтовой сети и компьютерное перевооружение почты. На втором этапе предполагалось завершить компьютерное и программное перевооружение, создание общереспубликанской информационной сети и системы электронной торговли, расширение спектра услуг и продуктов [4]. В результате проведенной реформы
Казахстан стал первым государством на территории СНГ, разработавшим почтовосберегательную систему. Учредителем АО "Казпочта" является Правительство РК. В 2006 году государственный пакет акций Компании был передан АО "Фонд национального благосостояния "Самрук-Казына".

В 2006 году АО "Казпочта" получило лицензию на осуществление трансфер-агентской деятельности на рынке ценных бумаг. В этом же году в г. Алматы было создано предприятие "Электронпост.kz" по предоставлению услуг информационной логистики. В 2008 году АО "Казпочта" открыло дочернее предприятие "Kazpost GmbH" в Германии для осуществления функций логистики, каталожной торговли, сбора и пересылки почтовой корреспонденции из Германии в Казахстан. В 2012 году в г. Астана было открыто первое в Казахстане круглосуточное отделение "Post-24". Отделение оказывает почтовые и финансовые услуги, обслуживая сотрудников более 30 министерств, ведомств, государственных холдингов, национальных компаний и жителей столицы [5].

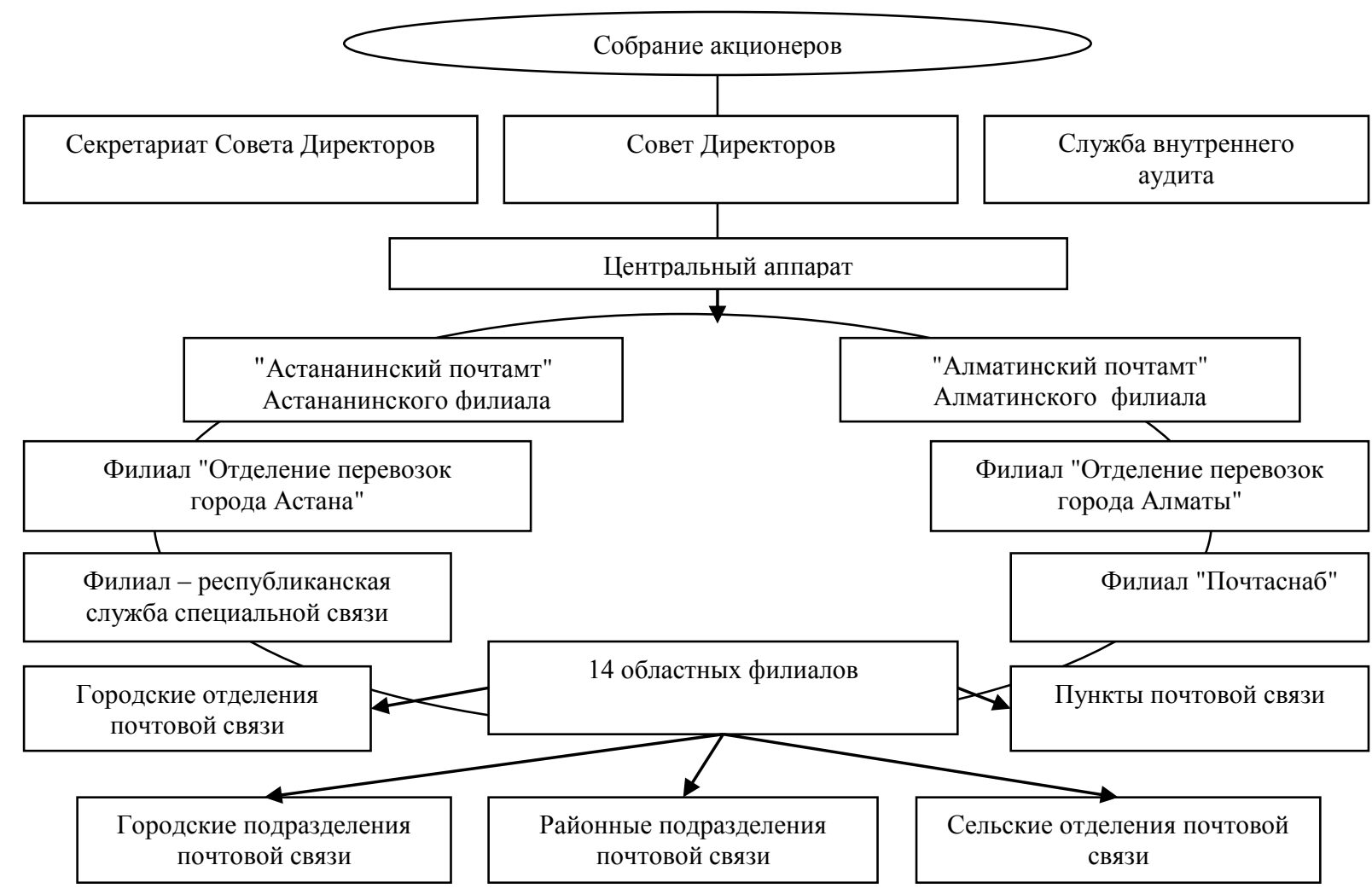

Рисунок 1 - Структурная и филиальная сеть АО "Казпочта"

Начиная с 2012 года АО "Казпочта" является проводников национальной инвестиционной программы "Народное IPO", предоставляя брокерские и транс-агентские услуги. В 2012 
году Всемирный почтовый союз вручил Компании сертификат о присвоении казахстанскому оператору почтовой связи уровня "В" ("серебряный" уровень) за управление качеством и как знак признания эффективности проводимых реформ.

Современная модель казахстанской почты включает черты небанковского финансового учреждения, оказывающего широкий спектр услуг - почтовых, агентских и банковских. Помимо традиционных видов услуг динамично развиваются новые направления деятельности: валютно-обменные операции, прием депозитов населения, операции на рынке ценных бумаг, инкассация и перевозка денег и ценностей, агентские услуги для пенсионных фондов и страховых компаний по привлечению клиентов и заключению договоров, курьерская служба EMS Kazpost. Разработаны и внедряются современные почтовые продукты - Direct-Mail, DirectMarketing, гибридная почта.

Деятельность АO "Казпочта" как национального оператора почтовой связи РК заключается в предоставлении клиентам полного спектра современных качественных почтовых, финансовых и логистических услуг на всей территории республики. Структурная и филиальная сеть Компании представлена на рисунке 1.

В соответствии с данными таблицы 1, в 2013 году доходы АО "Казпочта" составили 30489 млн. тенге, что ниже запланированного уровня на $6,3 \%$. За трехлетний период доходы Компании выросли на 28,5\%, а расходы - на $33,8 \%$. Превышение расходной части над доходами связано с существенным ростом общих и административных расходов, а также увеличением себестоимости продукции (услуг). Более высокие темпы роста расходов по сравнению с темпами роста доходов отразились на чистом доходе Компании. Наиболее низкий показатель чистого дохода зафиксирован в 2013 году [6, с. 23]. Следует заметить, что в этом году Компания планировала сокращение чистой прибыли до 266,6 млн. тенге, однако фактические данные оказались равными 164,5 млн. тенге, т.е. ниже запланированного уровня на $38,3 \%$.

\section{Динамика основных экономических показателей АО "Казпочта", млн. тенге.}

Таблица 1

\begin{tabular}{|c|c|c|c|c|c|}
\hline \multirow[t]{2}{*}{ Показатели } & \multicolumn{3}{|c|}{ Год } & \multicolumn{2}{|c|}{$\begin{array}{c}\text { Изменения } \\
2013 \text { г. к } 2011 \text { г. }\end{array}$} \\
\hline & 2011 & 2012 & 2013 & $(+,-)$ & $\%$ \\
\hline Общие доходы & 23723,0 & 27014,0 & 30489,0 & 6766,0 & 128,5 \\
\hline Общие расходы & 22709,0 & 25949,0 & 30377,0 & 7668,0 & 133,8 \\
\hline $\begin{array}{l}\text { Доля в доходах/расходах организаций, } \\
\text { учитываемых по методу долевого участия }\end{array}$ & $-3,0$ & 0,8 & 0,0 & $-3,0$ & - \\
\hline $\begin{array}{l}\text { Расходы по корпоративному подоходному } \\
\text { налогу }\end{array}$ & 203,9 & 119,4 & 357,1 & 153,2 & 175,1 \\
\hline Чистый доход/убыток & 806,5 & 945,8 & 164,5 & $-642,0$ & 20,4 \\
\hline
\end{tabular}

Доходы АО "Казпочта" формируются из доходов от оказания почтовых, финансовых и агентских услуг. Доходы от всех видов услуг имеют устойчивую тенденцию роста. За последние три года доходы от оказания почтовых услуг увеличились на 29,3\%. Это общедоступные услуги почтовой связи, услуги по пересылке регистрируемых почтовых отправлений, услуги ускоренной и курьерской почты, распространение печатных изданий по подписке и их реализация, реализация филателистической продукции, а также иные услуги почтовой связи. На рынке почтово-курьерских услуг доля АО "Казпочта" превышает 60\%. Остальная часть рынка приходится на частные курьерские компании, численность которых достигла 50. Несмотря на рост доходов Компании от оказания почтовых услуг, запланированный уровень не был достигнут. В первую очередь это связано с тем, что снизились весовые категории посылок, передаваемых для отправки компаниями дистанционной торговли.

Меньшими темпами увеличивались доходы от оказания финансовых услуг. К финансовым услугам Компании относятся услуги по доставке пенсионных выплат и социальных пособий, осуществление лизинговой деятельности, прием депозитов, кассовые и переводные операции, организация обменных операций с иностранной валютой, предоставление кредитов и т.д. При этом запланированные показатели по финансовым услугам не были достигнуты. Такое произошло в связи с невыполнением плана по выплате заработной платы в результате перехода части клиентов на зарплатные проекты в банках второго уровня с кредитным лимитом.

Наиболее высокие темпы роста доходов характерны для агентских услуг. За период с 2011 
за счет оказания почтовых услуг, $45,8 \%$ доходов

по 2013 годы они выросли более чем в 3 раза. Однако в структуре доходов Компании они занимают незначительную часть (рисунок 2). Половина доходов АО "Казпочта" формируется приносят финансовые услуги и $4,1 \%$ доходов агентские услуги.

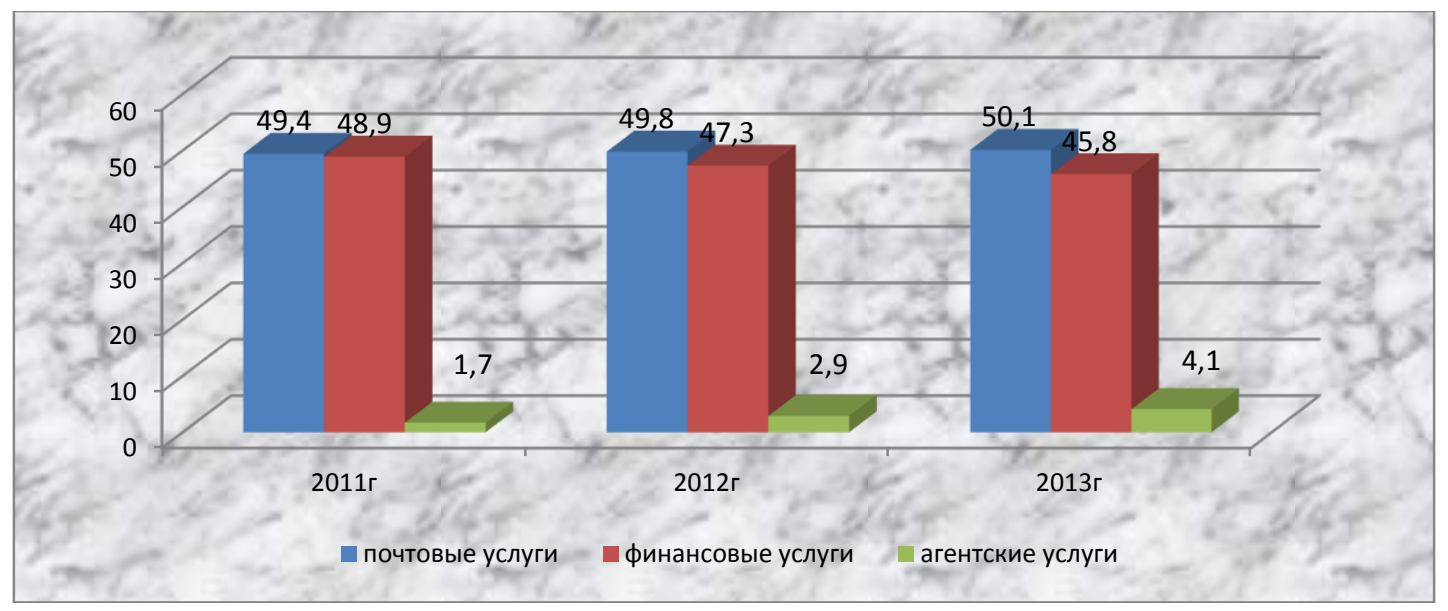

Рисунок 2 - Динамика структуры доходов АО "Казпочта", \%.

В общем объеме почтовых услуг наибольшую долю (около 60\%) составляют периодические почтовые издания. Причем их доля имеет тенденцию к уменьшению. Письменная корреспонденция составляет примерно пятую часть почтовых услуг и приносит Компании третью часть доходов от этого вида услуг. Но наиболее выгодной услугой является пересылка посылок. Так, составляя в общем объеме почтовых услуг всего лишь 1,2\%, эта услуга формирует четвертую часть доходов от этих услуг. Кроме того, для АО "Казпочта" весьма прибыльной является услуга ускоренной почты. К примеру, в 2011-2013 годах данный вид услуги в общем объеме почтовых услуг не превышал $0,1 \%$, а приносил Компании около десятой части доходов.

По сравнению с почтовыми услугами финансовые услуги Компании увеличивались меньшими темпами. Кроме того, стала снижаться доля доходов этих услуг в общих доходах АО "Казпочта". Основную часть финансовых услуг составляют услуги по выплате пенсий и пособий, приему платежей, денежным переводам. Несмотря на то, что услуги по приему платежей за последние три года увеличились на 45,9\%, а число принятых платежей превысило 55 млн. единиц, запланированные показатели не были выполнены. Это связано с тем, что банки второго уровня и АО "Казахтелеком" расширили собственную сеть терминалов самообслуживания, получили развитие такие альтернативные платежные системы как "Киви",
"Касса 24", "Авангард Plat" и другие. Наибольшую часть доходов от оказания финансовых услуг Компания получает от выплаты пенсий и приема платежей, которые формируют около $78 \%$ доходов от этих услуг.

В течение 2011-2013 годов Компания целенаправленно проводила политику наращивания своих активов. В этот период их рост составил 6275,14 млн. тенге или 29,8\%. Собственный капитал был увеличен на 2294821 тыс. тенге или на 24,9\% (рисунок 3). Это произошло за счет роста уставного капитала и фонда ценных бумаг, предназначенных для реализации.

Очевидно, что необходимость в собственном капитале обусловлена требованиями самофинансирования предприятия. Однако финансирование деятельности Компании только за счет собственных средств не всегда выгодно. Поэтому привлекая заемные средства, оно может повысить рентабельность собственного капитала [7, с. 98]. Одним из источников привлекаемых средств являются вклады населения. Однако ожидавшегося увеличения вкладов населения не произошло. Наоборот, в течение трех лет объемы вкладов клиентов уменьшились на 32768 тыс. тенге или на 24\%. Вклады клиентов включают вклады до востребования, текущие счета клиентов и срочные вклады. Среди них большую часть (около 80\%) составляют вклады до востребования (счета пенсий и пособий). 


\section{Impact Factor:}

ISRA $($ India $)=\mathbf{1 . 3 4 4}$
$\begin{array}{ll}\text { ISI (Dubai, UAE) } & =\mathbf{0 . 8 2 9} \\ \text { GIF (Australia) } & =\mathbf{0 . 3 5 6} \\ \text { JIF } & =\mathbf{1 . 5 0 0}\end{array}$

SIS (USA)

$=0.912$

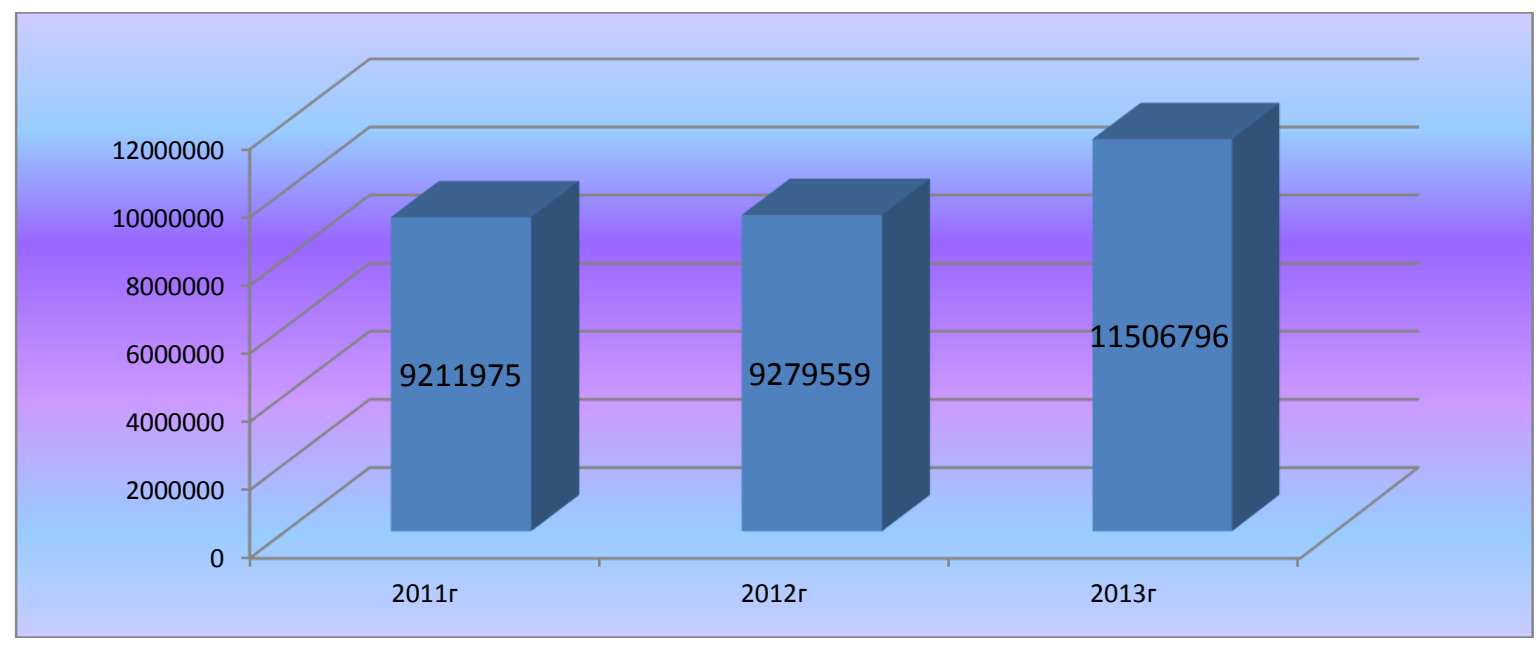

Рисунок 3 - Динамика собственного капитала АО "Казпочта", тыс. тенге.

Другим источником привлекаемых со стороны средств являются займы финансовых учреждений (таблица 2). Займы финансовых учреждений имеют устойчивую тенденцию роста и за три года увеличились в 2,5 раза. В 2013 году основными заемщиками АО "Казпочта" являлись Исламский Банк Ал Хилал, Исламский Банк Развития, Позитив Банк и Дойче Банк. Так, в мае 2013 года Компания получила необеспеченный займ от АО "Исламский Банк «Ал Хилал" в размере 1000 млн. тенге в рамках кредитной линии. Заем предназначался для финансирования капитальных затрат. Кроме того, в этом году Компания заложила основные средства на сумму 114289 тыс. тенге в качестве обеспечения по займу, предоставленному Исламским банком развития. Также был размещен долгосрочный депозит в "Альянс Банке" в качестве обеспечения по займу Исламского банка развития. В 2013 году АО "Казпочта" был привлечен очередной транш от АО "Банк Позитив Казахстан" на сумму 274 млн. тенге. Целевым назначением займа является финансирование капитальных затрат.

\section{Займы финансовых учреждений в 2013 году}

Таблица 2

\begin{tabular}{|l|c|c|c|c|}
\hline \multicolumn{1}{|c|}{ Учреждение } & Эфф. процентная ставка & Срок погашения & Валюта & Сумма \\
\hline Исламский Банк Ал Хилал & $7,35-8,42$ & Апрель 2017 г. & Тенге & 2343808 \\
\hline Исламский Банк Развития & 6,0 & Июнь 2019 г. & СДР & 868922 \\
\hline Позитив Банк & 9,23 & Март 2017 г. & Тенге & 231135 \\
\hline Дойче Банк & 8,99 & Ноябрь 2013 г. & Евро & 3635 \\
\hline
\end{tabular}

Очевидно, что АО "Казпочта" имеет большую зависимость от внешних инвесторов, что может негативно отразиться на финансовом состоянии Компании. Расчет коэффициента финансовой зависимости показал, что он превышает нормативное значение, тем самым подтверждая зависимость АО "Казпочта" от кредиторов (таблица 3 ).

Таблица 3

\section{Структура пассивов (обязательств) АО "Казпочта".}

\begin{tabular}{|l|c|c|c|c|}
\hline \multicolumn{1}{|c|}{ Показатель } & \multicolumn{4}{|c|}{ Уровень показателя } \\
\cline { 2 - 5 } & $2011 г$ & $2012 г$ & $2013 г$ & $\begin{array}{c}\text { Изменения } \\
\text { 2013г к 2011г }\end{array}$ \\
\hline $\begin{array}{l}\text { Удельный вес собственного капитала в общей валюте баланса } \\
\text { (коэффициент финансовой автономности предприятия), \% }\end{array}$ & 23,0 & 20,1 & 23,4 & 0,4 \\
\hline $\begin{array}{l}\text { Удельный вес заемного капитала (коэффициент финансовой } \\
\text { зависимости), \% }\end{array}$ & 77,0 & 79,9 & 76,6 & $-0,4$ \\
\hline В том числе: & & & & \\
\hline - долгосрочного & 5,2 & 7,2 & 8,0 & 2,8 \\
\hline - краткосрочного & 71,9 & 72,8 & 68,6 & $-3,3$ \\
\hline Коэффициент финансового риска (плечо финансового рычага) & 3,4 & 4,0 & 3,3 & $-0,1$ \\
\hline \hline
\end{tabular}

ISPC Intelligent technologies,

Marseille, France 
Коэффициент финансового риска имеет важнейшее значение для хозяйственной деятельности любого предприятия, поскольку позволяет оценить его финансовую устойчивость. Он представляет собой отношение привлеченных средств к собственному капиталу и дает возможность понять, какое количество средств, что были привлечены Компанией, приходится на единицу собственных средств. Оптимальное значение показателя составляет 0,5 [8, с. 135]. По данным АO "Казпочта" коэффициент финансового риска нестабилен, а его уменьшение в 2013 году незначительно и не может быть свидетельством возрастания финансовой устойчивости предприятия. Следует отметить, что чем выше уровень коэффициента финансовой автономности, а также чем ниже уровень коэффициента финансовой зависимости и коэффициента финансового риска, тем устойчивее финансовое состояние предприятия. Отсюда ясно, что финансовое состояние АО "Казпочта" является неустойчивым.
На современном этапе развития АО "Казпочта" рассматривает свою деятельность как часть реализации общей Стратегии инновационного развития Республики Казахстан и интеграции экономики страны в мировую экономическую систему, а ее почтового сегмента - в глобальную почтовую сеть. Бенчмаркетинг европейских и азиатских почтовых операторов позволяет утверждать, что видение будущего АО "Казпочта" соответствует стратегиям ведущих почтовых операторов мира (таблица 4). При этом большинство мировых почтовых операторов руководствуются в своей деятельности такими приоритетными понятиями, как "надежность и повышение качества" (почта Швейцарии), "доверие и доступность" (почта Японии), "развитие, инновации, эффективность и гибкость" (почта Италии) и "соответствие требованиям клиентов" (почта Великобритании) [9, с. 25]. Это говорит о том, что стратегическая политика АO "Казпочта" не противоречит мировой тенденции модернизации и расширения почтового бизнеса.

Таблица 4

Услуги почтово-сберегательных систем почтовых администраций отдельных стран мира.

\begin{tabular}{|c|c|c|c|c|c|c|c|c|c|}
\hline \multirow[b]{2}{*}{ Услуги } & \multicolumn{9}{|c|}{ Страны } \\
\hline & $\begin{array}{c}\text { Герма } \\
\text { ния }\end{array}$ & Швейцария & $\begin{array}{c}\text { Фран } \\
\text { ция }\end{array}$ & Япония & Россия & $\begin{array}{c}\text { Украи } \\
\text { на }\end{array}$ & Узбекистан & $\begin{array}{c}\text { Кирги } \\
\text { зия }\end{array}$ & $\begin{array}{c}\text { Казах } \\
\text { стан }\end{array}$ \\
\hline \multicolumn{10}{|c|}{ Почтовые услуги } \\
\hline Филателия & + & + & + & + & + & + & + & + & + \\
\hline $\begin{array}{l}\text { Консигнация, } \\
\text { товары-почтой }\end{array}$ & + & + & + & + & + & + & & & + \\
\hline $\begin{array}{l}\text { Услуги почтовой } \\
\text { прямой рекламы }\end{array}$ & + & + & + & + & + & + & & & + \\
\hline \multicolumn{10}{|c|}{ Финансовые услуги } \\
\hline $\begin{array}{l}\text { Почтовые } \\
\text { денежные } \\
\text { переводы } \\
\text { (внутренние и } \\
\text { международные) }\end{array}$ & + & + & + & + & + & + & + & + & + \\
\hline PKO & + & + & + & + & & & & & + \\
\hline Депозиты & + & + & + & + & & & & & + \\
\hline $\begin{array}{l}\text { Платежные } \\
\text { карточки }\end{array}$ & + & + & + & + & & & & & + \\
\hline Прием платежей & + & + & + & + & + & + & & + & + \\
\hline Брокерские услуги & + & + & + & + & & & & & + \\
\hline \multicolumn{10}{|c|}{ Агентские услуги } \\
\hline $\begin{array}{ll}\text { Услуги } & \text { по } \\
\text { агентским } & \\
\text { договорам } & \\
\end{array}$ & + & + & + & + & + & + & + & + & + \\
\hline
\end{tabular}

С целью улучшения финансовых позиций Компания разработывает планы развития на краткосрочные периоды. Так, стратегия развития AO "Казпочта" на 2011-2015 годы основана на концепции "трехмерной сети" услуг физических, электронных и финансовых. С целью реализации этой стратегии были определены цели, показанные на рисунке 4. 
Намеченные цели по модернизации, оптимизации, автоматизации бизнес-процессов в Компании являются частью общей инновационной концепции развития государственных компаний, реализуемой ФНБ "Самрук-Казына". Каждая компания государственного холдинга "Самрук-Казына" взяла на себя обязательство направлять на инновации не менее $10 \%$ чистой прибыли [10, с. 26]. В сегменте почтовых услуг Компания предполагает увеличить объем письменной корреспонденции до 4,4 млрд. тенге, освоить третью часть рынка по доставке рекламных материалов, занять лидерские позиции в сегменте ускоренной экспресс- и курьерской доставки. Вместе с тем, АО "Казпочта" планирует стать одним из первых в сегменте "посылочные отправления", стать главным партнером для предприятий дистанционной торговли и интернет-торговли. Особое внимание Компания концентрирует на деятельности, связанной с обслуживанием сельского населения. Также она собирается занять лидерские позиции в сегментах "райцентр" и "село" с предоставлением своих традиционных услуг, стать "выбором № 1" на уровне райцентра и села для страховых компаний и микрокредитных организаций.

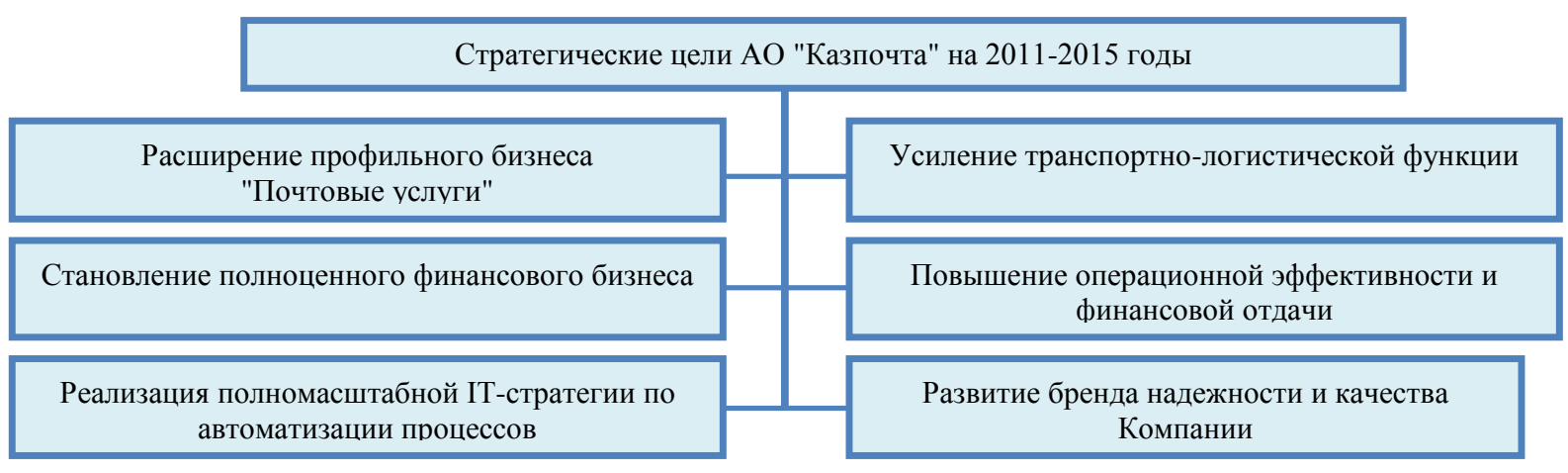

Рисунок 4 - Основные цели АО "Казпочта" в рамках реализации стратегии развития на 2011-2015 годы.

Очевидно, что достижение целевых индикаторов возможно при реализации инвестиционных проектов. Например, в 2011 году на реализацию 8 проектов было выделено 1632387 тыс. тенге. Все проекты были направлены на модернизацию и обновление производственных фондов. Кроме того, 10 млрд. тенге выделено на осуществление следующих проектов: создание филиала "EMS-Kazpost", "Мобильный Postman", поддержание в рабочем состоянии производственных активов и прочих основных средств.

Анализ производственно-хозяйственной деятельности АО "Казпочта", а также изучение его внешней и внутренней среды позволили провести SWOT-анализ деятельности Компании (таблица 5). Анализ сильных и слабых сторон, угроз и возможностей показывает состояние АО "Казпочта" на рынке в стратегическом аспекте.

Необходимо отметить, что разрабатывая планы развития на краткосрочный и долгосрочный периоды руководство $\mathrm{AO}$ "Казпочта" учитывает опыт ведущих Почтовых Администраций. В частности, для мировой почтовой отрасли как составной части мировой экономики основными концепциями успешного и стабильного развития выступают диверсификация и инновации. Указанные тенденции вместе с ключевыми концепциями успешного развития легли в основу разработанной Стратегии развития АО "Казпочта" до 2022 года [11]. Считается, что данная стратегия исправит отдельные недостатки, бессистемность планов развития Компании предыдущих лет. Однако принятая Стратегия должна стать не догмой, а канвой, позволяющей добиться намеченных целей и в тоже время дающей возможность своевременно вносить изменения и коррективы в программные документы АO "Казпочта" на краткосрочный и текущий периоды.

Нисколько не принижая роль и значение названной стратегии, считаем, что АО "Казпочта" следует разработать стратегию развития на краткосрочный период с учетом следующих предложений:

- разработка стратегии минимизации расходов, направленной на поиск возможностей по уменьшению издержек и сокращению затрат на неприбыльное производство. Но такая стратегия должна иметь кратковременный характер;

- в условиях наблюдающегося спада традиционных отправлений необходимо продолжение работы по поиску новых рыночных сегментов и проведению реструктуризации 
бизнеса. Это позволит диверсифицировать пакет бизнесов и выстроить востребованную на рынке модель услуг;

- разработка комплекса мер по повышению эффективности финансово-хозяйственной деятельности Компании. Эти меры должны быть направлены на уменьшение размера текущих финансовых обязательств предприятия в краткосрочном периоде и на увеличение объемов денежных активов, которые обеспечивают срочное погашение этих обязательств. При этом следует стремиться к обеспечению баланса денежных активов и краткосрочных финансовых обязательств;

- требуется пересмотреть финансовую стратегию, учитывая тот факт, что с капиталами краткосрочного использования необходима постоянная оперативная работа, направленная на контроль над их своевременным возвратом и привлечением в оборот других капиталов;

- в доходах Компании доминируют поступления от продаж низкорентабельных услуг. В то время как высоко рентабельные услуги (EMS, КГПО, спецсвязь, Direct Mail, зарплатные проекты) остаются прерогативой конкурентов. В связи с чем необходимо пересмотреть маркетинговую стратегию Компании;

- внедрение новых инфокоммуникационных технологий не только в производственный процесс, но и в систему управления;

\section{SWOT-анализ деятельности АO "Казпочта".}

\begin{tabular}{|c|c|}
\hline Сильные стороны & Слабые стороны \\
\hline $\begin{array}{l}\text { 1. Максимальный охват территории страны } \\
\text { благодаря созданию широкой почтовой сети }\end{array}$ & $\begin{array}{l}\text { 1. Незавершенная технологическая модернизация } \\
\text { и высокий износ основных фондов }\end{array}$ \\
\hline 2. Широкий ассортимент оказываемых услуг & 2. Низкая эффективность управления затратами \\
\hline 3. Конкурентные цены, особенно в сегменте EMS & 3. Низкая операционная эффективность \\
\hline $\begin{array}{l}\text { 4. Отрегулированный процесс предоставления } \\
\text { традиционных услуг, что связано со зрелостью } \\
\text { отрасли, сложившимся опытом }\end{array}$ & $\begin{array}{l}\text { 4. Высокие расходы на содержание филиальной } \\
\text { сети }\end{array}$ \\
\hline $\begin{array}{lll}5 . & \text { Постоянный поток клиентов, получающих } \\
\text { услуги } & & \\
\end{array}$ & 5. Высокая текучесть кадров \\
\hline $\begin{array}{l}\text { 6. Налаженные связи с зарубежными почтовыми } \\
\text { администрациями и Всемирным почтовым союзом }\end{array}$ & $\begin{array}{l}\text { 6. Недостаточный } \text { уровень } \\
\text { производственного персонала }\end{array}$ \\
\hline 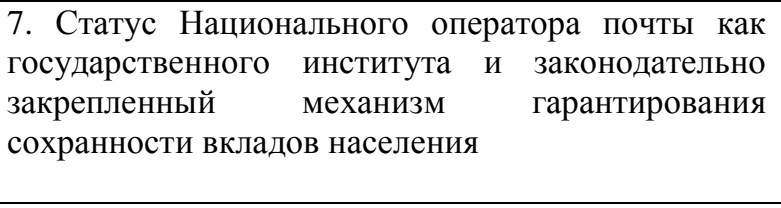 & $\begin{array}{l}\text { 7. Высокая конкуренция на городском уровне и } \\
\text { высокозатратная деятельность на сельском } \\
\text { уровне, связанная с текущим содержанием } \\
\text { распределенных производственных фондов по } \\
\text { масштабной почтовой сети }\end{array}$ \\
\hline Возможности & Угрозы \\
\hline $\begin{array}{l}\text { 1. Использование социальной } \text { значимости } \\
\text { Национального оператора почтовой связи }\end{array}$ & $\begin{array}{l}\text { 1. Отсутствие компенсации убытков } \\
\text { универсальных услуг почтовой связи }\end{array}$ \\
\hline $\begin{array}{l}\text { 2. Эффективное использование трехмерной сети } \\
\text { (физическая, электронная, финансовая) }\end{array}$ & $\begin{array}{l}\text { 2. Конкуренция на высокодоходных сегментах, } \\
\text { особенно в банковском сегменте }\end{array}$ \\
\hline 3. Государственная поддержка & $\begin{array}{l}\text { 3. Убытки по предоставлению услуг, тарифы на } \\
\text { которые регулируются государством }\end{array}$ \\
\hline 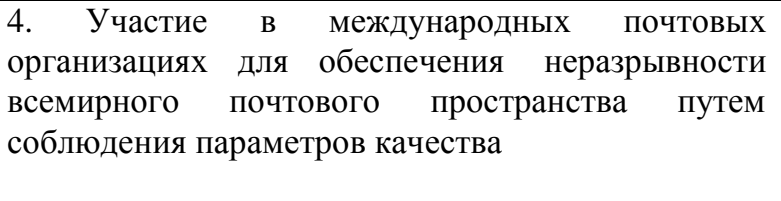 & $\begin{array}{l}\text { 4. Низкий уровень оплаты труда по сравнению с } \\
\text { коммерческими курьерскими компаниями и } \\
\text { банками вызывает отток профессиональных } \\
\text { кадров, что ухудшает качество предоставляемых } \\
\text { услуг }\end{array}$ \\
\hline $\begin{array}{llr}5 . \quad \text { Удобное } & \text { географическое } & \text { положение } \\
\text { республики, } & \text { использование } & \text { транзитного } \\
\text { потенциала } & & \end{array}$ & 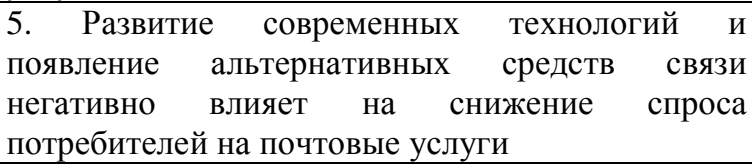 \\
\hline $\begin{array}{l}\text { 6. Внедрение инновационных технологий и } \\
\text { технических средств самообслуживания }\end{array}$ & \\
\hline $\begin{array}{l}\text { 7. Диверсификация деятельности } \text { (расширение } \\
\text { спектра услуг и клиентских рынков) }\end{array}$ & \\
\hline 8. Доверие клиентов & \\
\hline
\end{tabular}


продолжение

модернизации существующих и внедрение новых технологий. Технологическая политика должна строиться на расширении инновационных подходов, реинжиниринге процессов от разработки продуктов и услуг до выхода на рынок;

- охват доступным востребованным сервисом сельских населенных пунктов. Это государственные услуги, услуги по осуществлению заказов товаров по каталогам, страхование, брокерские услуги, кредитование, бронирование, покупка авиа- и железнодорожных билетов и прочие виды услуг. При этом Компания может действовать самостоятельно или в качестве агента других компаний;

- повышение доли эффективных услуг, подтвердивших коммерческую привлекательность. В частности, продвижение прямых почтовых рассылок рекламы; разработка целевого портфеля таких продуктов, как письма, посылки; модернизация работы сети филиалов и предложение рынку дифференцированных продуктов;

- создание логистической организации, которая будет заниматься аутсорсингом или оказанием логистических услуг; создание по опыту Японии при АО "Казпочта" банковской организации с целью развития сектора финансовых услуг;

- реализация проекта по созданию виртуальных бизнес-организаций, где АО "Казпочта" может выступить в качестве управляющей компании. Расширение сотрудничества с организациями, использующими методы сетевого маркетинга, с интернет-магазинами с целью оказания курьерских и иных услуг.

\section{References:}

1. (2015) History of JSC "Kazpost". Informational -analytical websites of Founds of "SamrukKazyna". Available: www.sk.kz/company (Accessed: 20.06.2015).

2. (1999) Government Resolution. On the reorganization of the Republican state enterprise of postal communication and its affiliated state enterprises: adopted December 20, 1999, № 1940.

3. (2006) Charter of JSC "Kazpost": approved by the Chairman of the Board of JSC "Kazakhstan Holding for Management of State Assets "Samruk"on July 7, 2006, № 15-p.

4. (2000) The decision of the Government of the Republic of Kazakhstan. On the program of development of postal sector of the Republic of Kazakhstan and the formation of the postal savings system, 2000-2003: approved November 15, 2000, № 1716

5. Kalinina E (2015) JSC Kazpost: today, in last and in the future // Available: www.kazpochta- vchera-segodnya-zavtra.html

(Accessed: 20.06.2015).

6. (2013) Annual report on the activities of "Kazpost" JSC for 2013 - Astana, 2013. - pp. 176.

7. Bocharev BB (2009) Financial analyze Course - SPb: "Piter Press", 2009. - pp. 240.

8. Keereva NV (2013) Financial end economical analyze. Course SRC - M. - INFRA-M, 2013. pp. 293.

9. (2013) Annual report on the activities of "Kazpost" JSC for 2012 - Astana, 2013. - pp. 88.

10. (2011) Explanatory note to the plan of "Kazpost" JSC for 2011-2015 - Astana, 2011. pp. 92.

11. (2013) The development strategy of "Kazpost" until 2022. Approved by the Board of Directors March 19, 2013, Minutes № 02/13. 